\title{
School Feeding and Food and Nutrition Security in the Context of the Covid-19 Pandemic in the Northern Region of the State of Rio de Janeiro, Brazil
}

\section{Ana Eliza Port Lourenço ${ }^{1}$ (D) Naiara Sperandio $^{1}$ (D) Priscila Vieira Pontes ${ }^{1}$ (D) Luana Silva Monteiro ${ }^{1}$ (D)}

Accepted: 3 June 2021 /Published online: 18 June 2021

(C) The Author(s), under exclusive licence to Springer Nature Switzerland AG 2021

\begin{abstract}
Due to the pandemic and the suspension of in-person school classes, there was an interruption in the meals served to approximately 40 million students who benefited from the Brazilian National School Feeding Program (PNAE). This article describes two case studies, comparing the strategies adopted by two municipalities for maintaining school feeding during the Covid-19 pandemic in the northern region of the state of Rio de Janeiro, Brazil, and discuss possible impacts of these strategies on food and nutrition security. These municipalities together cover about $81 \%$ of the population in the region. In July 2020, we conducted interviews with PNAE municipal managers, following a qualitative approach. We discuss the results in relation to existing Brazilian guidance on food and nutrition security. The municipalities have developed distinct strategies to overcome operational obstacles and maintain PNAE goals, such as distributing food kits and making cash transfers to students' families. The main determinants of these strategies are financial availability, the relationship between municipal teams and school communities, and the pre-pandemic PNAE logistics and management. Depending on the strategy and duration of the pandemic, the impacts on food and nutrition security can be wideranging, affecting food quality and local farmers who sell products to PNAE. It is necessary to acknowledge that this is not a short-term pandemic and find ways to perform school feeding in accordance with PNAE criteria.
\end{abstract}

Keywords Food and nutrition security $\cdot$ School feeding $\cdot$ Food assistance $\cdot$ Nutrition programs and policies $\cdot$ School health services

Ana Eliza Port Lourenço

aelourenco@gmail.com

1 Campus UFRJ Macaé Professor Aloísio Teixeira, Núcleo de Estudos em Saúde e Nutrição na Escola, Universidade Federal do Rio de Janeiro, Avenida Aloisio da Silva Gomes 50, Macaé, Brazil 


\section{Introduction}

Since February 2020, when the Covid-19 pandemic started globally, each country has tried to impede the transmission of the pathogen and exponential increase in the number of infected people and deaths. In the Brazilian context, diverse measures have been taken in different regions and states, especially the establishment of remote work and the suspension of inperson classes at public schools throughout the country (Brasil 2020a). As a result, there was an interruption in the meals served to approximately 40 million students who benefited from the Brazilian National School Feeding Program (PNAE) (Brasil 2009).

PNAE was created in the 1950 s, evolved through the years, and has become one of the most important food and nutrition programs in Brazil. The Constitution of Brazil, in tune with international perspectives concerning the human right to adequate and healthy food (United Nations 1999), ensures school feeding as a right of all students enrolled in public schools in the country (Brasil 1988). PNAE is currently a primary mechanism for ensuring this right and generating income to family farmers. Given its conception and magnitude, PNAE is recognized nationally and internationally as a main strategy to promote Food and Nutrition Security (FNS) in the country (Fanzo et al. 2013; FAO, IFAD and WFP 2014; Pedraza et al. 2018).

It should be noted that the PNAE does not focus only on disadvantaged groups. It is a nonprofit program that works entirely through public funding and comprises actions to promote adequate and healthy eating and psychosocial development, as well as meals to all students enrolled in public schools in the country. Besides food access, PNAE aims to promote nutrition education and prevent obesity as well as other health problems related to excess weight. This is particularly important because the nutrition transition in Brazil is characterized by an increase in the consumption of ultra-processed foods and prevalence of obesity (IBGE 2020b; da Louzada et al. 2015). PNAE covers pre-school, primary, middle, and secondary education, as well as adult education programs (Brasil 2009; de Machado et al. 2013). Therefore, all students are affected by PNAE interruption.

As the school calendar in Brazil begins late February, schools had just come back from summer vacation when the Covid-19 pandemic reached the country. Schools were closed without a contingency plan regarding remote education or school feeding. It is pertinent to note that the pandemic coincides with a period of a political crisis in Brazil. There is no strong leadership to guide the country in terms of national health and social policies (de Alpino et al. 2020). Thus, social movements and organizations came together to press for government measures to ensure the human right to adequate food in the country (de Carvalho et al. 2020; Comissão Organizadora da I Conferência Nacional Popular 2020).

Before the pandemic, PNAE guidelines required municipalities to offer meals at schools directly to students. By the federal law of April 7th, 2020, the Ministry of Education authorized municipalities to distribute food to students or their parents/guardians during an emergency (Federal Law 13,987) (Brasil 2020b). This regulation also stipulated that municipalities must ensure students' right to adequate food despite the crisis requiring the suspension of in-person education.

The municipalities had to develop their own strategies to maintain PNAE goals and in the process had to overcome multiple political and socio-cultural operational obstacles. The suspension of in-person classes in Brazil has lasted throughout the second semester of 2020, and school feeding remains in limbo in several locations in the country (da Pereira et al. 2020).

The interruption of classes interferes with the social relationships and effectiveness of the entire school community, along with the ways people work, learn, and eat. Also, a pandemic is 
a time of social and economic vulnerability, which increases the importance of PNAE as a strategy for FNS (United Nations 2020; de Ribeiro-Silva et al. 2020). It is noteworthy that for many Brazilian students, school feeding represents the main meal of the day (Peixinho 2013).

Considering the individual level, the pandemic may decrease or increase the intake of certain foods due to students being home longer. At the household level, changes can happen in the eating routine due to difficulties regarding going out to buy food and cooking more often, among others. Changes also tend to occur at the macrosocial level, impacting the food production system. Since 2009, it is stipulated by law that at least $30 \%$ of PNAE financial resources should be used to acquire foods from family farmers (Federal Law 11,947) (Pedraza et al. 2018; Brasil 2009). Therefore, numerous farmers who sell their products to PNAE have also been affected by its disruption.

The purpose of this study is to compare the strategies adopted by two municipalities for maintaining school feeding during the Covid-19 pandemic in the northern region of the state of Rio de Janeiro, Brazil, and discuss possible impacts of these strategies on FNS.

\section{Methods}

This article describes two case studies, comparing school feeding strategies adopted by two municipalities in the northern region of the state of Rio de Janeiro: Campos dos Goytacazes and Macaé. Together these municipalities cover about $81 \%$ of the population and comprise $76 \%$ of the students benefiting from PNAE in the region (FNDE 2020; IBGE 2020a).

In 2019, respectively for Campos dos Goytacazes and Macaé, the population was 507,548 and 256,672 inhabitants, and the population density was 115.16 and 169.89 inhabitants $/ \mathrm{km}^{2}$. The Human Development Index estimated in 2010 was equal to 0.716 and 0.764 (IBGE 2020a; United Nations n.d.). The estimated 2017 Gross Domestic Product (GDP) per capita was 43,000 reais in Campos dos Goytacazes and 63,000 reais in Macaé. Although the economy of both municipalities is based on the oil and gas production in the Campos Basin, most of the Petrobras (Brazilian Petroleum Corporation) offices, as well as many international oil-gas companies, are in Macaé. Therefore, Macaé is wealthier and has one of the highest GDPs in the country. Since 2017, however, rates of unemployment and social vulnerability have increased in both municipalities due to economic oscillations in the oil-gas production and inequality in income distribution (Lourenço et al. 2019; Silva Neto et al. 2019). Nonetheless, the municipalities have different financial resources and distinct histories of autonomy over school feeding management, which may shape different responses to the pandemic.

The PNAE covers about 52,000 students in 242 municipal public schools of Campos dos Goytacazes, and about 40,000 students in 108 municipal schools of Macaé. Starting in 2009 in Macaé, and in 2018 in Campos dos Goytacazes, school feeding has been outsourced. In this model, a third-party company is responsible for the preparation and distribution of meals at schools, while a municipal team of nutritionists is responsible for planning the menus and supervising the third-party services. Food and nutrition education actions in schools were to be carried out by both the external company and the municipal nutrition team.

In July 2020, we contacted the PNAE team in Campos dos Goytacazes and Macaé and asked to interview the current manager or a representative. Each municipality indicated one nutritionist (bachelor's degree in nutrition) with at least two years of experience in the local management of PNAE. Then we asked these two interviewees if there was another professional who also might speak for the PNAE in their municipality. There was no other 
professional in Campos dos Goytacazes, but one in Macaé. In all, we conducted interviews with three professionals who were able to provide crucial information and share their experience with PNAE management.

Interviews were conducted by video conference, following a qualitative approach. We used a script developed specifically for this study to identify the perceptions of the interviewees about obstacles and possibilities regarding school feeding. Interviews were recorded, transcribed, and analyzed by the authors via thematic analysis (Vaismoradi et al. 2013). Two previous thematic categories were considered: characteristics of the strategies adopted by the municipality to offer school feeding during the pandemic; and operational difficulties experienced in the school feeding at the municipal level. We discussed the results in relation to existing Brazilian guidance on FNS (Brasil 2006, 2010).

The interviewees signed a consent form electronically. In all quotes we used the male gender of writing and no interviewees' personal characteristics were detailed to maintain confidentiality.

\section{Results}

Early in the pandemic, both municipalities broke the contract with the third-party company, because the clauses related to food preparation and distribution were strict and thus difficult to adapt. The municipalities then took different paths to maintain PNAE goals during the school closures.

\section{School Feeding during the Pandemic in Campos dos Goytacazes}

Campos dos Goytacazes decided to distribute food kits to students. The distribution occurred for the first time in late May 2020 and has happened monthly since then. The foods are chosen by the municipal nutritionists and purchased with PNAE funds. The planning of kits included foods that had been part of the schools' menu and met PNAE nutritional requirements. However, due to cost limitations, some items were excluded, such as pasta and cornmeal. Macro and micronutrient values were calculated but, concerning meat or fish, "just sardines ended up staying in the kit" (Interviewee-A).

It has been a challenge to ensure adequate nutritional composition of food kits and meet the requirements established by law. The kits have included the following non-perishables: rice, beans, chocolate powder, milk powder, sweet biscuits, crackers, canned sardines, sugar, salt, and oil. Fresh foods, such as fruits and vegetables, were not included because "we were concerned about the logistics and distribution time. The municipality is $4,032 \mathrm{~km}^{2}$ large, it took approximately two to three weeks to complete the first month deliveries" (IntervieweeA).

There are also difficulties concerning the per capita value of each food item and its availability in the market. Each item should meet the needs of each age group and the number of meals each student would have at school per day. For example, in the case of oil, the nutritionists have considered an approximate value, because "when we multiply the per capita by the number of school days, we reach an amount that we can't find in the market; therefore, we ended up using $900 \mathrm{ml}$ as an oil unit" (Interviewee-A).

Campos dos Goytacazes hired another third-party company to purchase foods, assemble, and distribute the kits. The distribution happened at schools, and was organized by the 
principals, who have also been responsible for contacting students' families. Representatives of the municipal School Feeding Council - composed of education professionals, students, parents/guardians, civil society, and municipal employees - have participated in the process as well. Regarding nutrition and food education, the second kit distributed to families included a booklet on food hygiene.

As we can notice in the following quote, the municipality has made food kits available to all students, without determining priority groups, even though some families did not pick up the kits:

"We are attending to all students in all schools. We have not made a distinction or prioritization of students. What happened was that approximately 4,000 parents did not pick up the first kit at school. It was a low percentage, given the total number of students we have." (Interviewee -A)

\section{School Feeding during the Pandemic in Macaé}

Macaé is not distributing food kits. In late March 2020, Macaé established by law (Municipal Law 4676) the payment of emergency aid in the amount of 200 reais per month (approximately $20 \%$ of the current national minimum monthly wage) to all students enrolled in public municipal schools. According to municipal documents, the purpose of this aid, so called "Bolsa Alimentação," is to ensure that all students can eat during the suspension of in-person school activities. The monetary aid comes from municipal funds not linked to PNAE.

In April 2020, the aid was transferred for the first time directly to the checking account of one of the student's parents/guardians. But this action covered only about $36 \%$ of the beneficiaries because many of them did not have a bank account. The municipality then made a preloaded card available to parents/guardians. Yet, for those who could not come to school to pick up the card, the municipality released a payment order allowing parents/guardians to withdraw money from a local bank. By the end of April 2020, 81\% of the beneficiaries had received this aid, and by August this percentage had risen to $99 \%$.

Regarding education actions, educational materials on food and nutrition have been posted regularly on the municipality blog. These are texts, videos, and images with guidelines about healthy eating, cooking, and food hygiene, aligned with national recommendations (Ministério da Saúde do Brasil 2014; ASBRAN 2020). How many people actually can or do access it is unknown.

Even though the suspension of in-person classes has lasted months, the Bolsa Alimentação remains as the only school feeding strategy adopted in Macaé. As is evident in the following quote, there are logistical issues:

"Distributing foods in schools, who is going to do that? Who will separate foods and assemble each kit? Will we have to bid to purchase plastic bags to assemble the kits? We have the federal money to buy food, but we still don't know who and how we're going to distribute food." (Interviewee-B)

\section{Barriers Faced by both Municipalities in the Operationalization of School Feeding}

For both Campos dos Goytacazes and Macaé, purchasing products from family farmers is considered a challenge, even before the pandemic. While the interviewees recognize the 
importance of buying from local farmers, both in terms of their legal obligation to do so and in terms of supporting local farmers, they report the process of acquisition is bureaucratic and complicated.

Interviewees also mentioned that sometimes local farmers do not have enough products to meet PNAE requirements, and, even when they do, there are other challenges to overcome:

"I've tried to buy yogurt from family farmers, but then the school needs to store it, and many schools cannot. I have the responsibility for ensuring food hygienic-sanitary conditions from acquisition to consumption, and there are schools where the fridge barely works." (Interviewee-A).

Before the pandemic, Macaé bought foods from family farmers, even though it was difficult to reach the percentage required by law. In Campos dos Goytacazes, when school feeding was operated by the municipality without a third-party company, prior 2018, it was simpler to buy from local farmers. Since it has changed to outsourcing, the municipality could not purchase from them. The interviewees said that the outsourcing model has weaknesses and requires careful supervision, especially concerning food quality and purchasing from farmers:

"That public request for proposals worked very well, but that year [in 2017] we were still insourcing. But then we changed to outsourcing. We tried to do the public request, but the process was so bureaucratic, it took so long, the year passed, and it didn't happen. We have had many issues related to purchasing foods from family farmers." (Interviewee-A)

"The thirty-party company often tried to circumvent the minimum conditions of the contract, such as increasing the amount of ultra-processed foods, sometimes did not include foods from family farming. That was a fight! The company did not want to pay the price, as they claimed they could find the same foods for a cheaper price in the store. It took months of fighting for the company to agree. It was very exhausting, too bureaucratic." (Interviewee-C)

The interviewees also pointed out that PNAE managers feel insecure to deal with federal funds in terms of accountability. This fear is associated with the lack of preparation to work with finances and corruption in the country:

"I'd never imagined that it would be such a bureaucratic process, and we don't have much knowledge about these processes. (...) We are living a moment in the country when, due to overall national corruption, I might end up being accused by the federal prosecution. So, I don't feel comfortable making certain decisions." (Interviewee-A) "It's so exhausting. And this issue of using federal resources, there are many managers who are afraid of it. We are afraid of the prosecution of doing something wrong." (Interviewee-B)

"Most of the people who manage PNAE are very afraid of the government oversight." (Interviewee-C)

\section{Discussion}

The municipalities analyzed in this study have tried to keep PNAE goals during the suspension of in-person classes. This is an important result because not all the Brazilian municipalities are 
complying with legal recommendations regarding school feeding, especially in the state of Rio de Janeiro (Prefeitura do Rio de Janeiro 2020). Besides, PNAE is the main way to enact the students' right to healthy and adequate food in Brazil and promote FNS (de Machado et al. 2013; FAO, IFAD and WFP 2014). We may also see the continuation of PNAE as an ethical issue i.e., a morally-defensible practice that should remain even when conditions on the ground, such as the pandemic, impose obstacles.

In both Campos dos Goytacazes and Macaé, even though the school feeding tactics have problems, no disadvantaged groups of beneficiaries were determined, which is in accordance with PNAE precepts. The entirety of scope differentiates PNAE from other feeding programs internationally (e.g. Ralston et al. 2008; Fanzo et al. 2013). This is because the PNAE, in its current format, does not have social welfare as its only central assumption. PNAE is also a key-strategy to promote healthy eating habits and nutrition, and thus targets all students (Brasil 2009; Pedraza et al. 2018). Consequently, the explicit ethical principles underlying PNAE preclude establishing priority groups for food distribution based on a measure of variation in vulnerability, which itself was likely to be very fluid during the pandemic.

In terms of food access, a pandemic requires urgent actions because it can impact various sectors of society (Qiu et al. 2017; Elleby et al. 2020). Macaé was a pioneer compared to other municipalities in proposing an action regarding school feeding at the beginning of the pandemic. It is important to remember municipalities did not readily receive federal guidance and it took about two months for the federal government to publish the law that allows municipal managers to use the money from PNAE to distribute food to students through their parents/guardians. Information about the magnitude of the pandemic and safety procedures was also not made clear. Therefore, the cash transfer was a convenient strategy, relatively fast, and thus appropriate at that initial time. It is noteworthy that the distribution of food kits took about two months to start in Campos dos Goytacazes due a mosaic of obstacles.

However, a fundamental disadvantage of cash transfers is not guaranteeing the acquisition or quality of food. Consequently, it should not be the main strategy in the long term. It is relevant to mention that the concept of $\mathrm{FNS}^{1}$ adopted in Brazil goes beyond availability and food safety. It is a broad concept, which results from long-term efforts of social movements and governments and covers food adequacy in nutritional terms, along with cultural, social, economic, and environmental aspects (Brasil 2006, 2010; Leão and Maluf 2012).

Even if families decide to spend the monetary aid on healthy foods, they will have to pay a higher price. When purchasing on large scale by the municipality, it is possible to buy better quality food at a lower cost due to bulk discounted pricing. When the income is divided and families buy food at local retailers, the purchasing power is not the same. This is one reason why municipalities are not allowed to spend PNAE money via cash transfers. Families would end up receiving an insufficient amount of money, or municipalities would have to cover the higher cost, which is also not desirable for the use of public resources in the long term. The value transferred in Macaé is compatible with the price of basic food in the region, and it is more than double the amount paid in other nearby settings. Mainly because of a history of oil royalties, Macaé is a richer municipality and able to support these payments from their own

\footnotetext{
${ }^{1}$ In Brazil, Food and Nutrition Security is defined as "the realization of the right of all to regular and permanent access to quality food in sufficient quantity, without compromising access to other essential needs, based on nutrition practices that promote health, respect cultural diversity and are socially, economically and environmentally sustainable" (Brasil 2006). This definition results from long-term efforts of social movements and governments. It includes the noun "nutrition" to emphasize the inter-sectoral perspective between socioeconomic and health and nutrition approaches.
} 
(non PNAE) funds. Rio de Janeiro, for example, is another municipality that is making cash transfers, but the transferred value is 50 reais per month (about $5 \%$ the national minimum monthly wage), and only students considered more vulnerable have benefited (Prefeitura do Rio de Janeiro 2020). Since it is now allowed to distribute food to parents/guardians, municipalities should seek to perform PNAE accordingly.

It is also important to mention that the acquisition of food on large scales expands the possibility of partnerships with local cooperatives and farmers. On the other hand, at the family level, the purchase tends to happen mostly at grocery stores where, as a rule, there are a lot of products from the food industry and scarce locally-produced foods. Even in municipalities such as Macaé, where farmers' markets are common, it is complicated to ensure that the majority of the population can access these markets, especially during the pandemic, when only some markets are open, transportation is restricted and families' purchasing power may be smaller.

The partnership with family farmers has the potential to strengthen the regional economy, reduce poverty and food insecurity, and increase the supply of healthy, diverse, and culturallycontextualized foods (Fanzo et al. 2013; Pedraza et al. 2018). Due to this potential, part of the PNAE resources should be spent on foods from family farmers (Brasil 2009). Yet, from 2011 to 2017, Southeast Brazil was the region with the lowest percentage of food acquisition from local farmers (Araujo et al. 2019), and none of the municipalities in this study are currently buying locally. This promotes a disruption in the food system, with possible impacts on the supply and quality of food, as well as on the FNS of farmers.

The bureaucracy in the management of PNAE finances and worries related to accountability were the main difficulties mentioned by interviewees for the partnership with local farmers. Similar reasons were observed in a study carried out in different Brazilian capitals (Toyoyoshi et al. 2013). Federal guidelines for financial management are very strict and detailed. For example, as one of the interviewees mentioned, PNAE money cannot be spent on plastic bags, kitchen utensils or anything but food. On one hand, this prevents overall corruption. On the other hand, it may discourage appropriate action, especially because managers are afraid of making mistakes and being accused of mismanagement of public resources.

Interviewees also said that the outsourcing model presented challenges for assuring food quality. Although outsourcing may have operational advantages, it reduces the autonomy of the municipality over food management. Given that contracts with third-party companies are often inflexible with respect to what is up to employees and the characteristics of the service, the municipalities had to break the contracts in the pandemic. All of a sudden, the municipalities had no team to perform school feeding and also had no close interaction with local schools. This is a situation to learn from and take into consideration before signing new contracts, in order to avoid ineffectiveness and delays in decision-making in emergency situations.

If Macaé keeps performing only cash transfers, it will continue without partnerships with local farmers, which does not encourage FNS. The municipality should instead distribute meals or food as other locations have done. For example, in Curitiba, in the state of Paraná, food kits are being distributed in partnership with local farmers (Prefeitura de Curitiba 2020). In Taubate, in the state of São Paulo, food is being prepared at schools and distributed daily in packages to go (Prefeitura de Taubaté 2020).

Offering meals should be the strategy of reference because it is the most like the original PNAE and, as the experience in Campos dos Goytacazes shows, it may be difficult to provide nutritionally adequate food kits. Besides, PNAE targets are students (individual approach), not 
families (household approach). Transferring cash or distributing food kits does not guarantee intra-household resource distribution, and neither assures that someone will be available at home to cook, or appropriate preparation.

It would be valuable to develop additional research on the perceptions of the recipients of the PNAE and their utilization of the food aid during the pandemic. It was not possible to gather data from pupils or their parents/guardians for this study because most of them do not have internet access at home. As schools were closed without a contingency plan, we were not able to get contact information for the families at the beginning of the pandemic.

The Brazilian Food Guide recommends a daily diet that encompasses predominantly in natura or minimally processed foods, such as fruits, vegetables, rice, and beans; and that ultraprocessed foods, such as biscuits, snacks, and soft drinks should be avoided (Ministério da Saúde do Brasil 2014). This is because ultra-processed foods have undergone several industrial stages and usually have a high concentration of sugar, sodium, and poor-quality fat, in addition to low fiber levels (Monteiro et al. 2010). Moreover, the national guide encourages culinary practices, the consumption of foods from family farmers and foods of the local culture. The kits distributed in Campos dos Goytacazes include rice and beans, which are suitable in both nutritional and cultural aspects, and salt, sugar, and oil, which are culinary ingredients. However, the kits also contain ultra-processed products, such as chocolate powder and crackers, and do not contain fresh fruits or vegetables.

Ultra-processed products have become more common in Brazilian households, and the consumption of fruits and vegetables is below the recommendations (IBGE 2020b). This eating profile has been associated with a higher frequency of obesity and other diseases in Brazil (da Louzada et al. 2015). Schools are a remarkable social space for the prevention of these diseases, promote health, and protect students against exposure to unhealthy foods. In ordinary times, PNAE meals are freshly cooked and ultra-processed foods are highly restricted. At least once during the school day, students have a complete and balanced meal that encompasses a portion of meat or fish, rice and beans, as well as cooked vegetables, raw salad and fresh fruit (Brasil 2009).

Although school activities are happening remotely, school feeding should still contribute to healthy food habits. In fact, the role played by school feeding in promoting healthy eating can be even more critical in the pandemic. We are living a delicate moment, full of changes in the daily routine and, consequently, in food practices. Families may end up preferring ultraprocessed foods due to longer shelf life and convenience. Most students are at home with reduced physical activity and are often exposed to screens and food advertisements. In addition, the food and nutrition educational strategies developed by schools are restricted to digital media and not accessible to all.

Taking into account that the period at home already exceeds seven months and that there is no expectation of reopening schools in Brazil in 2020, it is relevant to be concerned about the formation of food habits during the pandemic. It is not just a few months of food exception, but a projection of at least one year of school closure. Therefore, school feeding during the pandemic should not be seen only from the perspective of availability. We should not lose sight of food quality and the role played by school feeding in the promotion of healthy and adequate food.

Regarding PNAE ethical principles, if it is deemed necessary alter current practices, it would likely be on a provisional or emergency basis, with an eye toward returning to the fundamental principles guiding PNAE. Although the pandemic experience provided (unwelcome) opportunities for revisiting those principles, we would argue that changes in 
PNAE should be made narrowly. That is because the PNAE was crafted through a comprehensive democratic process that was embedded in the history of food policies in Brazil. As other national policies developed with the support of the Brazilian National Council of Food Security (CONSEA), PNAE is a result of a bottom-up procedure. Therefore, wide-raging changes in PNAE may even extend ethical discussions into deliberative democracy and the ways policies are constructed in Brazil.

\section{Final Considerations}

We identified three main determinants of the food strategies adopted by the municipalities during the suspension of in-person classes: financial availability, the relationship between municipal nutrition teams and school communities, and PNAE logistics and management before the pandemic. Macaé has its own resources and has been outsourcing its school feeding for years. Thus, Macaé chose to make cash transfers as managers did not consider it feasible to distribute food in a decentralized way for each school. On the other hand, in Campos dos Goytacazes, where financial resources are relatively more restricted, and the nutrition team has a closer relationship with teachers and families due to the School Feeding Council and a long history of insourcing, food kits are being distributed. The distribution of meals was not mentioned as an option in either of the municipalities, which may be related to the abrupt breaks of contract with the outsourced companies and sudden lack of a team prepared for this task.

This study emphasizes that, depending on the duration of the pandemic, the impacts of school feeding strategies on FNS may be wide-ranging. Conditional cash transfers can be helpful in the short term but, in the long term, cash transfers should be replaced or complemented by meal or food distribution in order to promote FNS, not only in terms of access but also in terms of food quality.

Besides, some ethical issues are at stake. Beyond offering food access, PNAE is a broad public program, designed to promote healthy food habits and prevent diseases among all students in the country. Since PNAE is a moral practice, shaped through a long-term policy making process, it should continue during adverse conditions, and sub-optimal adjustments should be made provisionally with a time-index.

Operational limitations that already existed in the PNAE come to the forefront with the pandemic. Problems related to financial management are now greater, and neither of the two municipalities evaluated in this study are using federal resources to purchase food from local farmers.

This study highlights that it is necessary to reflect on school feeding management at the municipal level now as well as beyond the pandemic. Whether insourcing or outsourcing, it is essential to predict calamities and public health problems and reduce the bureaucracy of financial management in order to ensure the goals of PNAE and guarantee students' right to adequate school feeding.

Identifying local challenges and successes experienced in the north of the state of Rio de Janeiro may be useful for understanding vulnerabilities and solutions related to FNS in the country and globally. As a result of this study, we recommend that the municipalities should seek to offer meals or food in partnership with school communities and local farmers. It must be acknowledged that the pandemic is not a short-term situation, and the different actors involved in the PNAE should work together to overcome obstacles and perform school feeding in accordance with the program criteria. 
Code Availability Not applicable.

Authors' Contributions All authors contributed to the study conception and design. Interviews and data analysis were performed by Naiara Sperandio and Priscila Vieira Pontes. All authors worked jointly on writing and revising the manuscript.

Data Availability Not applicable.

\section{Declarations}

Ethics Approval This study was approved by the Research Ethics Committee of the Federal University of Rio de Janeiro, Campus of Macaé (registration number: 09414919.9.0000.5699).

Consent to Participate Informed consent was obtained prior to the interviews from all individual participants included in this study.

Consent to Publish The authors affirm that interviewers provided informed consent for publication of interview quotes.

Conflicts of Interest/Competing Interests The authors have no conflicts of interest to declare that are relevant to the content of this article.

\section{References}

de Alpino, T.M.A., C.R.B. Santos, D.C. de Barros, and C.M. de Freitas. 2020. COVID-19 and food and nutritional (in)security: Action by the Brazilian Federal Government during the pandemic, with budget cuts and institutional dismantlement. Reports in Public Health 36 (8). https://doi.org/10.1590/0102$311 \mathrm{X} 00161320$

Araujo, L.R.S., A.N.M. De Brito, M.T.P. Rodrigues, M.D.M. Mascarenhas, and R.S. Dos Reis Moreira-Araujo. 2019. School meals and family farming: Analysis of funds spent in food purchases. Cadernos De Saude Publica 35 (11). https://doi.org/10.1590/0102-311X00004819.

ASBRAN. Associação Brasileira de Nutrição. (2020). Guia para uma alimentação saudável em tempos COVID19. https://www.asbran.org.br/storage/downloads/files/2020/03/guia-alimentar-covid-19.pdf. Accessed 3 October 2020.

Brasil. (1988). Constituição da República Federativa do Brasil. Diário Oficial da União. http://www.planalto. gov.br/ccivil 03/constituicao/constituicao.htm. Accessed 2 October 2020.

Brasil. (2006). Lè Orgânica de Segurança Alimentar Nutricional (Losan). Lei no 11.346 , de 15 de setembro de 2006. Cria o Sistema Nacional de Segurança Alimentar e Nutricional-SISAN com vistas em assegurar o direito humano à alimentação adequada e dá outras providências. Diário Oficial da União. http://www4. planalto.gov.br/consea/conferencia/documentos/lei-de-seguranca-alimentar-e-nutricional. Accessed 3 October 2020

Brasil. (2009). Lei n ${ }^{\circ} 11.947$, de 16 de junho de 2009. Dispõe sobre o atendimento da alimentação escolar e do Programa Dinheiro Direto na Escola aos alunos da educação básica; altera as Leis nos 10.880, de 9 de junho de 2004, 11.273, de 6 de fevereiro de 2006, 11.507, de. Diário Oficial da União. http://www.planalto.gov. br/ccivil 03/ ato2007-2010/2009/lei/11 1947.htm. Accessed 3 October 2020.

Brasil. (2010). Décreto n. 7.272, de 25 de agosto de 2010. Regulamenta a Lei n. 11.346, de 15 de setembro de 2006, que cria o Sistema Nacional de Segurança Alimentar e Nutricional - SISAN com vistas a assegurar o direito humano à alimentação adequada, institui a Política. Diário Oficial da União. http://www.planalto. gov.br/ccivil_03/_ato2007-2010/2010/decreto/d7272.htm. Accessed 3 October 2020.

Brasil. (2020a). Lei $\mathrm{n}^{0} 13.979$, de 06 de fevereiro de 2020.Dispõe sobre as medidas para enfrentamento da emergência de saúde pública de importância internacional decorrente do coronavírus responsável pelo surto de 2019. Diário Oficial da União. http://www.planalto.gov.br/ccivil_03/_ato2019-2022/2020/lei/113979. htm. Accessed 3 October 2020.

Brasil. (2020b). Lei n.13.987, de 7 de abril de 2020. Altera a Lei $n^{\circ} 11.947$, de 16 de junho de 2009, para autorizar, em caráter excepcional, durante o período de suspensão das aulas em razão de situação de 
emergência ou calamidade pública, a distribuição de gêneros alime. http://www.planalto.gov.br/ccivil_03/_ ato2019-2022/2020/lei/113987.htm. Accessed 3 October 2020.

Comissão Organizadora da I Conferência Nacional Popular. (2020). Garantir o direito à alimentação e combater a fome em tempos de coronavírus : a vida e a dignidade humana em primeiro lugar !, 1-15. https://fbssan.org. br/wp-content/uploads/2020/03/2020-recomendacoes-sobre-direito-alimentacao-no-contexto-da-covid_.pdf

de Carvalho, C.A., P.C.A. de Fonseca, and N. Sperandio. 2020. How is Brazil facing the crisis of food and nutrition security during the Covid-19 pandemic? Public Health Nutrition 2014 (3). https://doi.org/10.1017/ s1368980020003973.

Elleby, C., I.P. Domínguez, M. Adenauer, and G. Genovese. 2020. Impacts of the COVID-19 pandemic on the global agricultural markets. Environmental and Resource Economics 76 (4). https://doi.org/10.1007/s10640020-00473-6.

Fanzo, J., Lachat, C., Sparling, T. (2013). The nutrition sensitivity of agriculture and food policies : a summary of eight country case studies No 402013 ISSN 1564-3743 In this issue : Changing food systems Programme News Speakers' Corner Publications Interview with Alan Berg Bulletin Board, (August 2014).

FAO, IFAD, WFP. Food and Agriculture Organization of the United Nations. International Fund for Agricultural Development. World Food Programme. (2014). The state of food insecurity in the world. Strengthening the enabling environment for food security and nutrition.

FNDE. Fundo Nacional de Desenvolvimento da Educação. (2020). Alunos atendidos pelo PNAE. http://www. fnde.gov.br/dadosabertos/dataset/alunos-atendidos-pelo-pnae-2014. Accessed 27 May 2020.

IBGE. Instituto Brasileiro de Geografia e Estatística (IBGE). (2020a). Cidades e estados do Brasil. https://www. ibge.gov.br/ cidades-e-estados. Accessed 27 May 2020.

IBGE. Instituto Brasileiro de Geografia e Estatística. (2020b). Pesquisa de Orçamentos Familiares - POF 20172018. https:/www.ibge.gov.br/estatisticas/sociais/saude/24786-pesquisa-de-orcamentos-familiares-2.html?= \&t=o-que-e. Accessed 1 October 2020.

Leão, M. M., Maluf, R. S. (2012). Effective public policies and active citizenship: Brazil's experience of building a Food and Nutrition Security System. (p.73).

Lourenço, A. E. P., Junior, H. S., Souza, I. L. de, da Amaral, I. S. T., Coelho, K. S. C., da Cruz, K. T., et al. (2019). Trajetória da Atenção à Saúde em Macaé: Desafios e Perspectivas. In Macae, do caos ao conhecimento: Olhares acadêmicos sobre o cenário de crise econômica. (p. 576).

da Louzada, M.L.C., A.P.B. Martins, D.S. Canella, L.G. Baraldi, R.B. Levy, R.M. Claro, et al. 2015. Ultraprocessed foods and the nutritional dietary profile in Brazil. Rev Saúde Pública 49 (38). https://doi.org/10. 1590/S0034-8910.2015049006132.

de Machado, P.M.O., M.S. de Machado, B.A.S. de Schmitz, A.C.T. Corso, D.A. González-Chica, and F.A.G. de, de Vasconcelos. 2013. Characterization of the National School Food Program in Santa Catarina state. Brazil. Rev Nutr. 26 (6): 715-725.

Ministério da Saúde do Brasil. (2014). Guia Alimentar para População Brasileira. Ministério da Saúde, Secretaria de Atenção à Saúde, Departamento de Atenção Básica, Coordenação Geral de Alimentação e Nutrição. https://bvsms.saude.gov.br/bvs/publicacoes/guia_alimentar_populacao_brasileira_2ed.pdf. Accessed 3 October 2020.

Monteiro, C.A., R.B. Levy, R.M. Claro, I.R.R. de Castro, and G. Cannon. 2010. A new classification of foods based on the extent and purpose of their processing. Cadernos de Saúde Pública 26 (11). https://doi.org/10. 1590/s0102-311x2010001100005.

Pedraza, D.F., F.A. Silva, E. Morganna, and N. Araujo. 2018. Evaluation of the National School Food Program : Review of the literature. Ciência \& Saúde Coletiva 23 (5). https://doi.org/10.1590/1413-81232018235. 17832016.

Peixinho, A.M.L. 2013. The trajectory of the Brazilian School Nutrition Program between 2003 and 2010 : report of the national manager. Ciência \& Saúde Coletiva 18 (4): 909-916.

da Pereira, A. S., Campos, F. M., Santos, C. R. B., de Lima, E. C. S., Mocellin, M. C., do Serra, G. M. A., et al. (2020). Challenges of the national school meals program during the COVID-19 pandemic. Brazilian Journal of Development, 6(8) https://doi.org/10.34117/bjdv6n8-674.

Prefeitura Municipal de Curitiba. (2020). Decreto no 604. https://mid.curitiba.pr.gov.br/2020/00298164.pdf. Accessed 3 October 2020.

Prefeitura Municipal de Taubaté. (2020). Prefeitura inicia distribuição de alimentação escolar nesta terça-feira. https://www.taubate.sp.gov.br/noticias/prefeitura-inicia-distribuicao-de-alimentacao-escolar-nesta-tercafeira/. Accessed 3 October 2020.

Prefeitura Municipal do Rio de Janeiro. (2020). Prefeitura começa a distribuir cartões alimentação para todos os alunos da rede de ensino municipal. https://prefeitura.rio/educacao/prefeitura-comeca-a-distribuir-cartoesalimentacao-para-todos-os-alunos-da-rede-de-ensino-municipal/. Accessed 3 October 2020.

Qiu, W., S. Rutherford, A. Mao, and C. Chu. 2017. The pandemic and its impacts. Health, Culture and Society 9: 1-11. https://doi.org/10.5195/hcs.2017.221. 
Ralston, K., Newman, C., Clauson, A., Guthrie, J., Buzby, J. (2008). The National School Lunch Program : Background, Trends, and Issues. Economic Research Service, 61.

de Ribeiro-Silva, R.C., M. Pereira, T. Campello, É. Aragão, J.M.M. de Guimarães, A.J.F. Ferreira, et al. 2020. Covid-19 pandemic implications for food and nutrition security in Brazil. Ciencia e Saude Coletiva 25 (9). https://doi.org/10.1590/1413-81232020259.22152020.

Silva Neto, R., de Brito, F. S. R., Filho, P. G. R. (2019). Crescimento versus desenvolvimento socioeconômico: Uma análise do município de Macaé a partir dos anos 2000. In Macaé, do Caos ao conhecimento: olhares acadêmicos sobre o cenário de crise econômica (pp. 33-47).

Toyoyoshi, J.Y., R. de Oliveira, M.S.N. dos Santos, M.S. Galisa, and A.P. Galante. 2013. Evaluation of the acquisition of food items from family farming for school meals. O mundo da Saúde 37 (3): 329-335.

United Nations. (n.d.). Desenvolvimento Humano e IDH. https:/www.br.undp.org/content/brazil/pt/home/idh0. html. Accessed 3 October 2020.

United Nations. (1999). General comment no. 12: The human right to adequate food (art.11). https://www. refworld.org/pdfid/4538838c11.pdf

United Nations. (2020). Policy brief: Impact of COVID-19 on food security and nutrition (FSN). United Nations, 1-23. http:/www.ceigram.upm.es/wp-content/uploads/2020/03/HLPE.-Impact-of-COVID-19-on-FSN2020-03-24.pdf

Vaismoradi, M., H. Turunen, and T. Bondas. 2013. Content analysis and thematic analysis : Implications for conducting a qualitative descriptive study. Nursing and Health Sciences 15. https://doi.org/10.1111/nhs. 12048.

Publisher's Note Springer Nature remains neutral with regard to jurisdictional claims in published maps and institutional affiliations. 